\title{
An Analysis Of Women Leadership: Telescoping Benazir Bhutto And Indira Gandhi In South Asia
}

\author{
Fauzia Ghani \\ Department of Political Science \\ Government College University, Lahore \\ Muhammad Ali \\ Department of Political Science \\ University of Karachi
}

\begin{abstract}
Societies are made or marred by leaders. The rise and fall of dynasties are also due to the role played by the leaders. It is an acknowledged fact that leaders are the central actors of most of the activities of the world. Their dynamic role can determine the fate of the society in the context of politicoeconomic changes in positive manners. It is generally fixed impression that qualified leaders are rare and when it comes to woman leadership the fact becomes more accurate as women leadership is not experienced by many states. No matter, women have been playing a decisive role in all walks of life; however, it is evident that their participation in political matters and affairs as a leader is limited. When it comes to the case of South Asian politics, the women leadership is marginalized either due to their own training or because of prevailing political norms where male bias is unavoidable. This paper argues that in South Asian States particularly India and Pakistan, women leadership is not a regular feature of their politics rather they succeeded their father's i.e. Benazir Bhutto and Indira Gandhi. Furthermore, this paper aimed at to give an insight to leadership qualities of both South Asian women leaders in connection with their polities. To narrow down their role, some variables have been chosen (Economic development, reorientation of political parties and women empowerment and participation).
\end{abstract}

Key Words: Leadership, Women Leadership, Charismatic leadership, Male chauvinism, Trait Theory, Participative theory, Economic development, Relationship theory, Islamic Socialism 


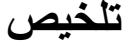

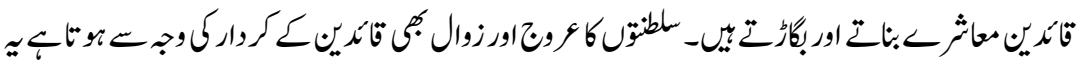

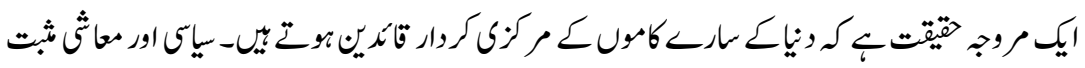

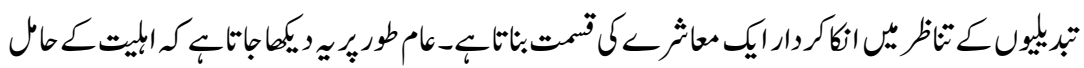

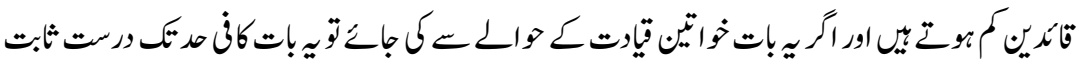

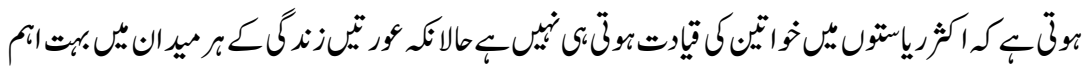

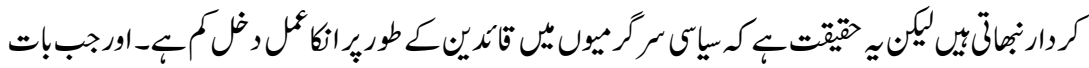

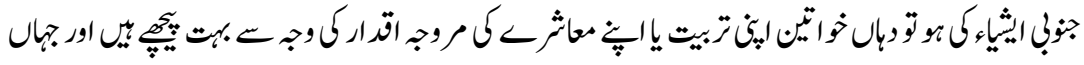

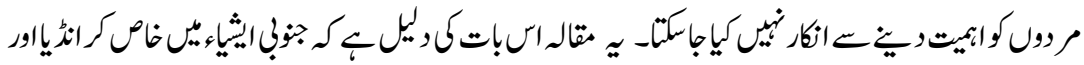

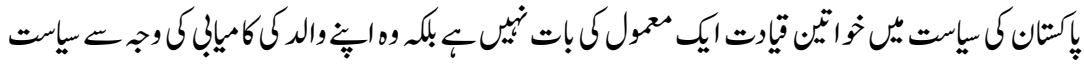

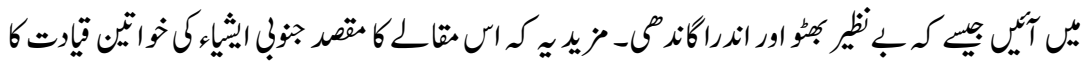

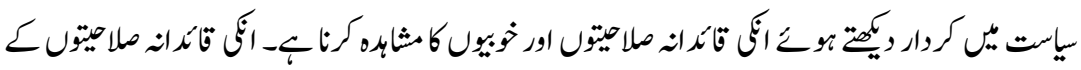

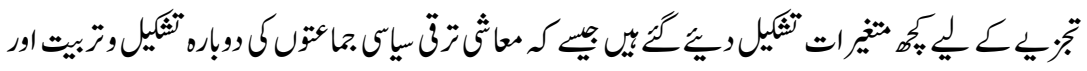

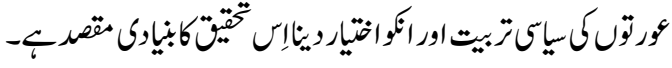

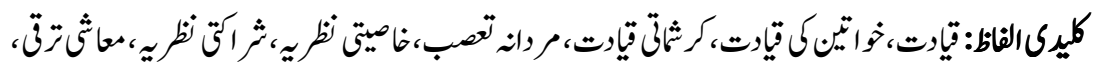

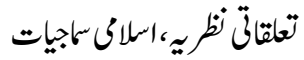

\section{Introduction}

Leadership is considered as the back bone of a political system. As it is generally said that the failure and the performance of a state depends only on the leader's role, therefore, their presence in the society cannot be overshadowed. It is also noticed that often leaders played the central and decisive role particularly in shaping and reshaping the structure and functions of any state. Leader's perception, qualities, training, belief, all do matter in analyzing his/her role in any polity. While particularly talking about South Asian states, Pakistan and India despite the fact that they had the colonial experience produced dynamic leadership of women, Benazir Bhutto and Indira Gandhi. The fact however, cannot be ignored that they remained under pressure in performing their duties assigned by the constitution. There is a need to evaluate their role in this context. 
This article, therefore, aims at explaining the concept of leadership and women leadership for analyzing the role of Benazir Bhutto and Indira Gandhi as leaders. For this purpose three variables have been selected. The emphasis here is on the various qualities and perspectives of leadership which can be helpful for understanding the role of women leadership in South Asian Politics. The analysis is confined to two states of South Asia i.e. India and Pakistan. Benazir Bhutto and Indira Gandhi both have been taken as case study. Furthermore, three factors/ variables are under consideration economic development/reform, reorientation of political parties and women participation. Before women leadership in politics of South Asia is to be analyzed, it is pertinent to shed light on the very concept of leadership and women leadership to encompass the role of two leading women Benazir Bhutto and Indira Gandhi in Pakistan and India respectively.

\section{Conception of Leadership and Women Leadership}

Leadership is a complex phenomenon, it has different meanings. Warren Bennis, a theoretician has dealt leadership in both qualitative and quantitative context. $\mathrm{He}$ sanctioned that leaders are natural as well as made. According to him "leaders play a central role in bringing enormous changes in a society" (Bennis, 1994). Geraint Parry explained leadership as "small minorities who play an exceptionally influential part in politics and social affairs" (Parry, 1977). Operational definition of leadership is that Leadership is the phenomenon in which who has got capabilities to take decision regarding the lives of the people. Scholars have analyzed phenomenon of leadership from various dimensions and perspectives. There is a lot of literature present that helps in understanding the leadership phenomenon. It is generally accepted that there is qualified leadership to play a fundamental role in politics of states. Aristotle believes that traits of leadership are naturally rooted in human beings. Due to those qualities they make their position dominant and efficient in the society (Ghani, 2012). There are various models and theories of leadership e.g. trait theory, great man theory, contingency theory, situational theory, behavioural theory, participative theory, management theory, relationship theory which highlight the patterns of a successful leader. For this research paper an effort has been made to see the qualifications and role of women leadership under the paradigm of Trait Theory. Further, leadership models help to understand what actually a leader should be. When leadership concept is to be analyzed in the context of women, it becomes interesting. As compared to

male leadership which has been experienced by all states, women leadership is more dynamic and assertive. In various societies, the women leadership is not 
observed as regular feature. Particularly talking about third world countries, women participation is minimized. The continuing discussion analyzes the women leadership of Benazir Bhutto and Indira Gandhi.

\section{Women Leadership in South Asian Politics}

In South Asian countries, (Bangladesh, Bhutan, India, Maldives, Nepal, Pakistan, Sri Lanka and Afghanistan) there are certain factors which depict the culture of politics like social inequalities based on caste, creed and gender, division of the language and religion lack of economic resource management. From the last 50 years, India and Sri Lanka had the democratic governments. Pakistan and Bangladesh is shuffling with democracy, militarism and autocracy. Nepal shifted from democracy to absolute monarchy and then again came to democratic system. Sharma (2011) in her article "Women Leader and Situation of Women in South Asia" has stated that many women entered in the circle of power in South Asia. The position of Sri Lanka is best in South Asia with $45^{\text {th }}$ position. Bhutan and Nepal stands in $64^{\text {th }}$ and $65^{\text {th }}$ position respectively.

Women leaders coming to power is one of the positive indicators of women advancement and gender equity but the fate of many average South Asian women has remained unchanged despite the progressive scenario of famous women leaders assuming leadership in the region. The reason behind this is dynastic politics. The women's leadership in this region mostly doesn't accounts as a process of gradual development and did not emerge naturally. Most of the women leaders began taking interest in politics only after the assassination or death of their fathers or husbands. It is also acknowledged by Pandey (2005) in his book "South Asia: Policy, Literacy and conflict Resolution, Politics of South Asia" that South Asian women leader gets her legitimacy from a dead leader though they are able to enter in the politics. This phenomenon of capturing women as a leader in politics of South Asia is leaving limited options for those women who are not part of dynasties.

South Asian Women's Representation in Parliaments shows that many countries in this region have remained unsuccessful in giving the actual space to women in politics. The highest rank of women in Parliament is in Nepal which is 33.2\%, Afghanistan 27.7\%, Bhutan 24.0 \%, Pakistan 33\%, Bangladesh 18.6\%, India $10.7 \%$ and Sri Lanka $5.8 \%$ is on the lowest position on women participation in politics (UN Women, 2012). Below table is showing the detail of women leaders in various countries of South Asia in different time periods. 
Women Heads of State and Government in South Asia

Since Independence

\begin{tabular}{|c|c|c|c|}
\hline Country & Name & Office & Period \\
\hline \multirow[t]{2}{*}{ Bangladesh } & Khaleda Zia & $\begin{array}{c}\text { Prime Minister } \\
\text { (Parliamentary } \\
\text { System) }\end{array}$ & 1991-96, 2001-06 \\
\hline & $\begin{array}{c}\text { Sheikh } \\
\text { HasinaWajed }\end{array}$ & $\begin{array}{c}\text { Prime Minister } \\
\text { (Parliamentary } \\
\text { System) }\end{array}$ & $\begin{array}{c}\text { 1996-2001, 2009- } \\
\text { present }\end{array}$ \\
\hline \multirow[t]{2}{*}{ India } & Indira Gandhi & $\begin{array}{c}\text { Prime Minister } \\
\text { (Parliamentary } \\
\text { System) }\end{array}$ & $1966-77,1980-84$ \\
\hline & PrathibaPatil & President (appointed) & $2007-2012$ \\
\hline Pakistan & Benazir Bhutto & $\begin{array}{c}\text { Prime Minister } \\
\text { (Parliamentary } \\
\text { System) }\end{array}$ & 1988-90, 1993-96 \\
\hline \multirow[t]{2}{*}{ Sri Lanka } & $\begin{array}{c}\text { Sirimavo } \\
\text { Bandaranaike }\end{array}$ & $\begin{array}{c}\text { Prime Minister } \\
\text { (Parliamentary } \\
\text { System) }\end{array}$ & $\begin{array}{c}1960-65,1970-77 \\
1994-2000\end{array}$ \\
\hline & $\begin{array}{c}\text { Chandrika } \\
\text { Kumaratunga }\end{array}$ & $\begin{array}{c}\text { Prime Minister } \\
\text { (Parliamentary } \\
\text { System) } \\
\text { President (direct) }\end{array}$ & $\begin{array}{c}1994 \text { (3 months) } \\
1994-2005\end{array}$ \\
\hline
\end{tabular}

Source: Asian Centre for Women's Studies; EWHA Woman University Press, Vol.18 No.2, 2012

The low participation of women in politics is generally due to male dominance in politics. That is why women's leadership is directly affected by patriarchal trends. They have to adjust in male dominated culture. Keeping in mind this fact, it is agreed by some scholars that in politics often women are recognized having less leadership qualities as compared to men. The similar political actions done by women and men in leadership conditions are estimated more negatively when leaders are women. In South Asia, the actual role of women in politics is limited. However, Pakistan, India, and Bangladesh have all had at the position as a wheel of their countries. In India, Indira Gandhi presided over the world's largest democracy. Benazir Bhutto became the first Muslim Prime Minister of Pakistan and she served for two terms. Moreover, Sheikh Hasina and Khaleda Zia have been the women leaders of Bangladesh, world's largest Muslim democracy for 
two decades. Benazir Bhutto and Indira Gandhi both have some similarities on some matters but their personalities and political achievements are different from each other. Main similarities between them were that both were the daughters of the Prime Minister and assassinated by terrorist groups within their countries.

\section{Benazir Bhutto and Indira Gandhi}

In 1988, Benazir Bhutto became the first woman Prime Minister of Pakistan and also a first woman elected to lead a Muslim world. Benazir Bhutto remained very famous and contentious politician in her both tenures of 1988 and 1993. Shafqat (1996) in her Journal "Pakistan under Benazir Bhutto" has narrated that she was considered as courageous in confronting military rule and also eased in the process of a democratic transition. She wanted to change Pakistan into a state having economic development, social tolerance and democratic stability. But she did not fulfill these goals up to satisfactory level. Benazir came in the state as leader who has significant personality trait of ability to convince. She started different developmental programs for Pakistan like aerospace projects, modernization of atomic weapons programs and research programs. Pakistan was the first Muslim country who placed the satellite in Earth on 1990 which was the remarkable achievement of Benazir Bhutto's regime.

Coming to an overview Indira Priyadarshini Gandhi's leadership, she was the first woman Indian politician and second female head of government in the world who served for four terms. The tenure of her service in India was from 1966-1977 and 1980-1984. Still Gandhi is considered as the World's Second longest female Prime Minister who served her blood to the country. She was the lady of extraordinary qualities, as she impressed the whole world by her traits. As it is observed by Steinberg (2005) in his article "Indira Gandhi: The Relationship between Personality Profile and Leadership Style" explored that Indira Gandhi was a very versatile woman leader of the India, as in her personality there were four qualities ambitious, reticent, contentious, and dominating which indicates her personality traits. Gandhi's daughter inherited the traits of charismatic leadership from him. Her ability and skills towards the policies were extremely manly. Her slogan of campaign was "Abolish Poverty", which resulted in considerable decrease of the percentage of population of India below the poverty line. She was admired by people but also hated by many politicians for her charismatic personality and political wisdom. To evaluate the role of leadership of Benazir Bhutto and Indira Gandhi, the following factors/ indicators are focused. 
1. Economic Development and Reforms

2. Reorientation of Political Parties

3. Women Empowerment and Participation

\section{Leadership Style of Benazir Bhutto Economic Development/ Reforms}

Benazir Bhutto agreed to set a two-fold policy in order to encourage economic transformation. The first step taken by Pakistan People Party (PPP) was to move away from socialist policies set by Zulfiqar Ali Bhutto, while Benazir was promoting private sector involvement in the economy. Benazir believed that the private sector is the source of economic growth and development. She advocated non-governmental investment in the industry. More focus was given on exchange rate policy and agriculture subsidies were removed.

During her first tenure, she initiated stabilization and adjusment programs such as sales tax and low tariff rate. The second important step taken by Benazir Bhutto was the provision of investment funds for private sector. Private sector was provided an easy access to finances from government owned banks. It was noted that during her first tenure she could not give much importance to the economy of Pakistan. She did not make serious efforts for denationalization. Economy was not liberalized during Benazir Bhutto's first government. She tried to lower development expenditure but was unable to control military spending. But in 1993, when Benazir Bhutto was re-elected as Prime Minister, she struggled and tried to reinforce economic reforms which were liberal in nature. She did her best to continue this struggle for liberal economy. Privitization was again implemented which was based on four basic principles;

a. Privatization will be carried out to do good to all.

b. The main purpose of privatization is to make industry more competent and resourceful.

c. It should be apparent and impartial.

d. Privatization is carried out to avoid creation of monopolies.

The process of privatisation was continued in different sectors of the economy such as telecommunication, WAPDA, industry, commercial banks, power generation and other financial institutions. Value-added tax (VAT) was introduced in Benazir's second tenure. It was applicable on manufacturing sector. The limitations on current account transactions were abolished. In order to reduce the cost of inputs, tariffs were lowered. Development plans were made for energy 
sector. It was the prime focus of Benazir's second tenure. Her second tenure was considered as successful in maintaining economic stability. Citizens were allowed to keep foreign exchange accounts. All currency restrictions were removed for Pakistani citizens. As far as, economic reforms of Benazir Bhutto were concerned, they were rejected by rulimg elite such as landlords of Punjab and Sindh and the civil bureaucracy. The new taxes introduced during Benazir's time period left deep impact on urban middle class. But those taxes were unable to affect higher economic elites and bureaucrates.

\section{Reorientation of Political Parties and Benazir Bhutto}

Political Parties from which Benazir Bhutto and Indira Gandhi contested elections were the most popular parties of both the countries at that time. They were elected as Prime Minister of their respective countries on the strength of their parties. When we compare Indira Gandhi and Benazir Bhutto with respect to political parties, they emerged as social icon at worldwide. Leading political parties always give contentment and success to their leaders, side by side people also hold that party. Other parties were not so much strong as Benazir Bhutto's Peoples Party and Indira Gandhi's Indian National Congress. Indira Gandhi's party Indian National Congress promoted women representation in parliaments as compared to other parties in India.

Benazir Bhutto belonged to Pakistan Peoples Party (PPP). She was the Chairperson of this party, as party was one of the famous political Parties in Pakistan. As a leader she believed that:

"Leadership is a commitment to an idea, to a dream, and to a vision of what can be. And my dream is for my land and my people to cease fighting and allow our children to reach their full potential regardless of sex, status, or belief' (Benazir Bhutto).

On a socialist mandate of "Roti (bread), Kapra (clothes), Makan (shelter)", Benazir's party won its elections in 1988 on the basis of its political manifesto, before that her father won the Pakistan's first general elections in 1970 on the same creed. The party slogan was "Islam is our faith, democracy is our politics, and socialism is our economy, all power to the people" (Manifesto of PPP, 1988). The motto of Benazir's party was to embrace Pakistan with success and development under Islamic Socialist ideas. Benazir's party actively participated in restoration of democracy. She challenged Zia's authority in 1986, when she came 
back from self-exile. The Movement for Restoration of Democracy (MRD) was established to replace the fundamental Islamization of the country. From different sections of Pakistani society like Baluchs, Shiaites, Pathans, Sindhi's and Benazir's own party (PPP) participated in this movement and stood against martial law regime of Zia-ul-Haq. They wanted liberal thought of system, comprehensive system, a system towards democracy and for this reason they choose Benazir Bhutto in 1988 elections of Pakistan. Her party easily defeated conservative Islamic Democratic Alliance. For Benazir Bhutto, this election was a battle against the monsters. PPP sacrificed lives of twenty thousand workers for the Pakistan. As she was daughter of Charismatic leader, thousands of supporters welcomed her to Pakistan. She struggled hard throughout in her life, being a daughter of great politician. She was much confident on her struggle that she would found justice in Pakistan and democracy will prevail in the country as she wrote in her book that:

"Just as flower cannot bloom in a desert, political parties cannot flourish in a dictatorship. That the political parties have managed to survive and flourish despite their lives for democracy...we are the conscience of the country..." (Bhutto, 2008). She achieved victory on the grounds of her father's policy.

Though, she determined to face the system and confronted to the people, to accept the challenge to shift the system from military dictatorship to the management of democracy. Her main agenda was on high priority to social sectors like education, clean drinking water, sanitation, energy and health. To transform the fruits of democracy and freedom all over the Pakistan, budgetary allocations in respective fields was enhanced. Benazir Bhutto promised to the nation that her party will facilitate them by the following acts:

1. Enhancement of education

2. Braced relations with the United States, Soviet Union and China

3. Sheltered minority rights

4. More provincial autonomy

5. Beginning of a broad national health policy

6. Mobilization for the rights of women

7. Payment, according to the nature of the work

She could not accomplish most of these goals. The realities of her party's aim did not transformed into action. Main downfall of her political party could be seen in 1990 when she and her husband Asif Ali Zardari charged with corruption. In 
1993, Pakistan Peoples Party came in government with new agenda which was "Agenda for Change" Priorities given to the social sector and at the front-door step of the people. Mohtarma Benazir Bhutto gained heavy mandate in all the provinces of Pakistan and was elected again Prime Minister of the Pakistan.

\section{Women Empowerment and Participation}

Women play an important role in the path of decision-making in the development process across broad range of sectors. Particularly, there is growing momentum among governments to promote and ensure women's leadership and participation in governance structures in the political arena. The 1988 elections manifested as a significant landmark for women empowerment as Benazir Bhutto contested election for the first time, as first female Prime Minister of Pakistan. Adding up that after a long period of 11 years, these elections were based upon first party elections. These were the first party based elections after a gap of 11 years. Women involvement in these elections traced a slight decrease. Women contested only 38 national and provincial seats in which 6 were won. Out of 38 seats, National Assembly was 17 seats, Punjab Assembly 13, Sindh Assembly 5, NWFP 2 and 1 seat from Baluchistan Assembly. Six seats which were won in this election distributed as National Assembly got 4 seats, Punjab and NWFP Assembly got only 1 seat respectively. With respect to women's representation, the 1993 elections observed a slight increase in the figure of women general seats contested. Total seats contested by women were 41 of National Assembly and only 7 seats resulted in success. Out of 16 seats from National Assembly, women preserved 4 seats, Punjab, Sindh and NWFP got 1 seat each. While comparing women representation in Lok Sabha of India with the National Assembly of Pakistan in the respective time period of Indira Gandhi and Benazir Bhutto, it is noticed that participation of women in politics in India is less than Pakistan. Women attained highest representation in Lok Sabha in 1967 election of Indira Gandhi which was 31 seats preserved by women. On the contrary, women obtained highest ratio of women's representation in 1993 election of Benazir Bhutto which was 41 seats. So this shows that role of women in Pakistan is higher than in India. As motto of Benazir Bhutto was to ensure the rights of women in all fields. Benazir Bhutto emphasized much on issues of women than Indira Gandhi. While comparing Pakistan with the India, women participation in parliaments of Pakistan is more than India. Pakistan People's Party was driving force in empowering and mobilizing women in the politics. At times of Benazir Bhutto, there was no trend of women in Politics but her agenda of empowering women in 
every field proved herself. The increase in representation of the female in Parliament of Pakistan made easier for women to acquire its important position in the government. Dr. Fehmida Mirza of Benazir Bhutto's party leader proved herself a strong woman while elected as first speaker of the National Assembly not only in Pakistan but also in the Muslim World. Benazir Bhutto ensured the role of women in politics not in Pakistan but also in South Asia. According to the Australian Magazine in 1996, list of 100 most powerful women was published in which Benazir Bhutto was one of them.

Benazir Bhutto was determined in the cause of Gender Equality in her both the regimes of 1988 and 1993. Her party was the only party headed by a woman Prime minister. Her party pronounced national employment policy for women in public service in which $10 \%$ job quota for women was affirmed in action. It is said by her party that legal ownership of resources and assets of women would be enable through effective legislation. Party also failed in preventing women from crimes like forced marriages and honor-killings, in establishing family courts headed by women judges to hear the Family Law Cases. Right of child custody did not fulfilled by her government. "Women will be selected at the higher judicial level" she even did not fulfil this statement. Department of women development will be attached with the main policy making bodies for the gender concerns. This announcement also did not accomplish. Benazir Bhutto could have change the situation of women while she was in her period of premiership but she did not.

\section{Leadership Style of Indra Gandhi Economic Development and Reforms}

It is mostly believed that leaders with charismatic personality try to bring essential changes in policy making and policy development. After coming into power Indira Gandhi's prime goal was to improve production. She believed that unsuccessful socialism halts economic growth. Putting more focus on private enterprise, agriculture production was increased and it led to green revolution. The new model of development initiated by Indira Gandhi was based on three components; economic growth is the main goal of the state, big business to be involved to achieve this target and giving due importance to labour force as an important tool of this objective.

When she came back in politics in 1980, she had introduced pro-market reforms. Indira Gandhi favoured private sector for economy growth and moved away from 
the concept of socialism. The Monopolies and Restrictive Trade Practices which put limits on big business to grow, was abolished and all restrictions were removed. All big businesses were allowed to expand in core industries such as drugs, cement, ceramics and chemicals. For the growth of business, government had opened credit for borrowers and labours made more active while passing special bills which stop labour's strike and involved them in the production process in more cooperative manners. Likewise Benazir Bhutto, Indira Gandhi was also criticized on her earlier economic policies. The criticism was made by national press, Janta, government, and intellectual community. Indira Gandhi wanted to change Indian economic strategy but was unable to do so. She could not use her talent in economic dominion.

\section{Reorientation of Political Parties}

Indira Gandhi belonged to Indian National Congress which was one of the famous political parties in India and oldest Democratic Parties in the world. Her party's manifesto stated that "We are a party with a glorious past. We are the Party of the future. It is for us to ensure that it holds out hope for each and every Indian. That is our calling and our obligation. Let the message go forth from this Plenary that the Congress is aware of its strengths, conscious of its responsibilities. Together we will build on our strengths. Together we will honour our responsibilities. Together we will strive our utmost to prove worthy of the trust and confidence that the people continue to repose in us" (Congress Party's Manifesto, 1970s). Indira Gandhi also focused in her manifesto towards economic policy. She wanted to grab the popular support for her party while introducing popular agenda. That's why she used slogan 'Garibi Hatao' Congress Party's manifesto (1970) and for the strategic purposes, she builds close relations with the Soviet Union. She grew more despotic and repressive in her all type of politics. The entrance in politics of Indira Gandhi is also because of the death of Shri Lal Bahadur Shastri in 1966. Her Political Party was very famous that she was elected again prime minister of India in 1980. Indira Gandhi focused on education in her manifesto and to some extent she fulfilled it by executed the mid-day meal scheme, benefiting many students in schools.

\section{Women Empowerment and Participation}

In India, according to the article 14 of the Constitution, all women are equal in their fundamental rights, in voting rights and also in political participation. Preamble tells that Indian Constitution decisively based on the principle of 
freedom, equity, integrity and numerous provisions related to empowerment of women. Over the past few decades, however, the status of women has been passed from different changes. No doubt that woman enjoyed the high offices like Prime Minister, Speaker of the Lok Sabha and Leader of the opposition. But women in India are still facing many social problems. The low representation of women in political system of India depicts the low position of women in the society especially in the context of high rate of crimes and violent behaviour against women, unequal status in different fields like in education, health sectors, employment etc. Through the history of India, 14 general elections represent the low level of women participation in the Parliaments and State legislatures. Women got less than $8 \%$ of Parliamentary, less than 6\% in Cabinet, less than $4 \%$ in High Courts and less than 3\% administrator's seats (UNIFEM, 2000).

Women representation in Lok Sabha of India is comparatively low as compared to men. In 1967, total seats were 523 in which female got only 31 seats and male got 492 seats, total percentage was 5.93. In the next election of 1971, total seats were 521, where men got 499 seats and women got 22 seats, percentage was 4.22. This shows that in 1971, women representation in Lok Sabha was declined by the previous election. This was the time to empower the women because Indira Gandhi was at that time on high rank as a prime minister of India. Similarly, in 1977 total seats were 544 in which women got only 19 seats and men got 525, it is the lowest figure of women representation in Indira Gandhi's Premiership and it is also noticed in 1980's election that women got 28 seats which is comparatively high figure with the previous election. The sixth Lok Sabha election 1977 to 1980 considered as the lowest representation of women in the history of India. The level of women representation was not satisfactory to the extent to which it should be in Indira Gandhi's time period.

In Indira Gandhi's first election in 1967, total seats were 240 where males got 220 seats and female attained only 20 seats. In the next election of Gandhi females took 17 seats as well as males took 226 in Rajya Sabha. Then again in 1977 and 1980, women get 25 and 24 seats respectively as men got 219 and 220 out of 244 in both the elections. In the 1977, women showed $10.25 \%$ highest figure in Indira's regime. In Rajya Sabha that women are below the average level of men's representation. Women are facing hurdles in participation of political system. As there is no women empowerment and mobilization agenda for them.

Indira Gandhi did not achieve that status of women which she could have done. At that time, they have the chance to facilitate the poor women but her policies 
were failed in it. Same as at times of Benazir Bhutto's premiership, the level she could achieve for women she never reached at that time. After Benazir Bhutto and Indira Gandhi's assassination, the level of women mobilization and participation in politics has increased in both countries as well as in South Asia because of their strength and will in politics. Now in Pakistan as well as in India women have to some extent the power and rule to the politics.

\section{Conclusions}

In any country, women's participation in ordinary political activity is significant connotation for the large arena of governance. Liberal democracy is always noticed on law, cause and free will but the situation of many social groups in their respective areas where generalization of power is not fully practiced equally. This is what, indicating the case of women. The nature of society or state has a crucial impact on the efficiency of women's political existence and contribution. Often, inadequate role of women participation and representation in national politics has some major consequences on them.

Benazir Bhutto and Indira Gandhi both were active and dynamic leaders in their time. They have served nations by doing efforts in policy making. Pakistani society is patriarchal in nature which exhibits male dominance over female members. Though, the teachings of Islam support equal treatment with women. However, the socio-cultural discrimination against women is still hampering the way of women development. Women are being empowered in social, political and economic spheres as education and civil society is creating consciousness among women. Benazir Bhutto experienced pure feudal system of Pakistan. Being known as Daughter of East, she encouraged women from all over the world to stand up and show their potential. She was famous for her determined capacity which is required for running an administration. Indira Gandhi being a first woman leader came into politics and proved her abilities to run a country, her economic performance can be used to evaluate her leadership style. She was able to develop strategic relationship with world super powers like United States and Soviet Union. Political Party of Indira Gandhi was famous for its democratic movements. In order to develop India, a model was given based on the fact that the economic growth is the main component of development. Leaders like Indira Gandhi and Benazir born once in a century, and there is no other leader who can replace them in context of women leadership, however could not bring any significant change in the socio-cultural status of South Asian politics generally and women in particularly. Due to the 
existence of century's patriarchal mind-set, this hardly accepts women as an equal gender however, Benazir and Indira made efforts to increase the ratio of women participation in the political process of their respective countries.

\section{References}

Bennis, Warren, (1994). On Becoming a Leader, New York: Warren Bennis Inc, p.39

Bhutto, Benazir, (2008). Reconciliation, Islam, Democracy and the West, London: Simon and Schuster.

Desai, Maghnad \& Ahsan, Aitzaz (2005). Divided by Democracy, New Delhi: Roli Books, p.66

Ghani, Fauzia, (2012). Leadership a Complex Phenomenon: A Glimpse on the Elected Leadership of Punjab, Berekly Journal of Social Sciences, vol. 2:12.

History of LokSabha Elections http://www.smetimes.in/smetimes/general-elections2009/miscellaneous/2009/Mar/23/history-of-lok-sabha-elections5584.html, retrieved on January 25, 2015

Katherine Frank (2010) Indira: The Life of Indira Nehru Gandhi, Available at ebook: http://www.goodreads.com/book/show/290376.Indira.

Lok Sabha, http://en.wikipedia.org/wiki/Lok_Sabha, Retrieved on April 22, 2013

Manifesto - (1970) Indian National Congress inc.in/images/pages/English\%20Manifesto \%20for\%20Web.pdf Retrieved on October 22, 2015

Manifesto - 1988 - Pakistan Peoples Party, www.ppp.org.pk/manifestos/manifesto1988. pdf, retrieved on October 22, 2015

Nandy, A. (1989). The Political Culture of the Indian State, American Academy of Arts \& Sciences, vol.118:4, p.4

Pandey, Aditya (2006). South Asia: Polity, Literacy and Conflict Resolution, Isha Books, India. Retrieved on January 24, 2014

Shafqat, S. (1996). Pakistan under Benazir Bhutto, The Regents of the University of California, Asian Survey, vol.36:7, p.655

Sharma, S. (2011). Women Leader \& Situation of Women in South Asia, New Delhi: Roli Books, p.76 
Steinberg Blema S. (2005), The Relationship between Personality Profile and Leadership Style. Volume 26, Issue 5, pages 755-790, Available at http://onlinelibrary.wiley. com/doi/10.1111/j.1467-9221. 2005.00443.x/abstract Retrieved on October 11, 2015

Tamarana, S. (2012). Political Empowerment of Women in India: A Study on Smt. Indira Gandhi, International Journal of Multidisciplinary Educational Research, vol. $1: 1$, pp.251-255

The 7 Traits of Great Leaders, www.calipercorp.com/portfolio/the-7-traits-of-greatleaders/, retrieved on January 11, 2015

The New Encyclopaedia Britannica, Vol.vi. 15 editions, Chicago: Encyclopaedia Britannica, Inc. 1978.

UN Women, http://www.unwomensouthasia.org/, Retrieved on January 11, 2014

UNIFEM (2000). UN Women http://www.unifem.org/worldwide/asia_pacific/index.html, retrieved on January 14, 2014

Weems, Z. (2012). Indira Gandhi and the Indian Emergency, Poetic Reflections, http://ryanweberling.com/citylit/indira-gandhi-and-the-indian-emergency/, retrieved on January 15, 2014

Women in Parliaments: World Classification http://www.ipu.org/wmn-e/classif-arc.htm, retrieved on January 11, 2014

Fauzia Ghani is Assistant Professor in the Department of Political Science, Government College University, Lahore.

Dr. Muhammad Ali is Assistant Professor in the Department of Political Science, University of Karachi. 